\title{
Help seeking amongst child and adolescent victims of peer-aggression and bullying: The influence of school-stage, gender, victimisation, appraisal, and emotion.
}

\author{
Simon C. Hunter, James M.E. Boyle*, and David Warden \\ Department of Psychology, University of Strathclyde, UK
}

*Requests for reprints should be addressed to James Boyle, Department of Psychology, University of Strathclyde, Graham Hills Building, 40 George Street, Glasgow G1 1QE, UK (e-mail: j.boyle@strath.ac.uk).

Running title: Help seeking amongst the victims of peer-aggression.

Published, full reference is:

Hunter, S.C., Boyle, J.M.E. \& Warden, D. (2004). Help seeking amongst child and adolescent victims of peer-aggression and bullying: The influence of school-stage, gender, victimisation, appraisal, and emotion. British Journal of Educational Psychology, 74 (3), 375-390.

http://onlinelibrary.wiley.com/doi/10.1348/0007099041552378/abstract 


\section{Help seeking amongst child and adolescent victims of peer-aggression and bullying: The influence of school-stage, gender, victimisation, appraisal, and emotion.}

\section{Background}

\section{Abstract}

An important element of many anti-bullying programmes is encouraging victims to tell someone about their predicament. Research has already reported prevalence of telling, who/when children tell and efficacy of telling. However, seeking help can be viewed as a coping behaviour, and coping processes such as appraisal and emotion may be important predictors of whether pupils ask for help.

\section{Aims}

To examine the effects that background (gender, school-stage), victimisation (duration, frequency), appraisal (threat, challenge, control) and negative emotion have upon support seeking by child and adolescent victims of peer-aggression and bullying. To also examine the how effective pupils perceive social support to be.

\section{Sample}

Participants were 830 children (49\% male) aged 9 - 14 years. Three hundred and seventeen pupils were in Primary Six, 306 in Secondary Two and 205 in Secondary Three.

\section{Method}

A self-report bullying questionnaire was completed by the participants within their classes. Questionnaires included items relating to victimisation, appraisal, emotion, and coping strategy choice as well as demographic data.

\section{Results}

Hierarchical multiple regression analysis revealed that gender, challenge appraisals, and emotions were significant predictors of the degree to which child and adolescent victims of peer-aggression and bullying sought help (accounting for $15.8 \%$ of the variance): girls were more likely than boys to seek help, as were pupils with high challenge appraisals or those experiencing high levels of negative emotion. Also, girls were more likely than boys to view support as the best strategy for both stopping bullying and for helping them to feel better.

\section{Conclusion}

Results suggest that pupils are more willing to seek help when they see the situation as one in which something can be achieved. Pupils also may be seeking support to get help coping with negative emotions, and this may need to be emphasised to teachers. 


\section{Introduction}

An important element of many anti-bullying programmes is encouraging victims to tell someone in order that they can be helped to resolve the situation (Glover, Gough, Johnson and Cartwright, 2000). Indeed, trainee teachers report that this is the number one coping strategy that they would recommend to students (Nicolaides, Toda and Smith, 2002). Usually, victims of school bullying are advised to tell teachers when they are bullied, but they are also encouraged to speak to their parents/guardians. Furthermore, in recognition that not all pupils wish to speak to teachers or parents/guardians about such an issue, peer support systems have been developed in which students are used to tutor, to reinforce positive behaviour, and to council or advise other pupils (Naylor and Cowie, 1999; Smith and Sharp, 1994). It is thus important that we understand why children and adolescents turn to others for help, as well as who they ask, as such information might help those advising/helping victims to better understand what is expected, or asked, of them.

Research has already begun to make headway on collection of prevalence data in this area, as can be seen from Table 1. Overall, it appears that younger victims of school bullying turn to others for help in dealing with bullying more than do older victims (Borg, 1998; Glover et al., 2000; Hunter and Boyle, in press; Sharp, 1995). In addition, a repeated finding is that girls are more willing to seek help than are boys (Glover et al., 2000; Hunter and Boyle, in press; Sharp, 1995; Talamelli, Smith, Cowie, Naylor and Chauhan, submitted). 


\section{Table 1 about here}

Regarding who students turn to for help, Glover et al. (2000) report that, among 11-16 year olds, telling a friend is most common, followed by mother, and then form tutor. However, in the same age-range, Talamelli et al. (submitted) found that students most often spoke to their parents, followed by their friends, and then their teachers. Why this discrepancy exists is not clear, though it may rest upon the fact that Glover et al. used a self-report survey methodology as opposed to the structured interview methodology of Talamelli et al. (submitted). Pateraki and Houndoumadi (2001), with a younger sample (7-11 years old), found victims were equally likely to seek help from adults and friends. While they also used a self-report survey methodology, their failure to distinguish between parents/guardians and teachers means it remains unclear whether there is a discernible developmental trend in whom students ask for help.

Regarding gender differences, Borg (1998) reports that girls aged between nine and 14 years old are more likely to seek help from a best friend or parent while boys are more likely to ask for help from a friend or teacher. Further, there also appear to be differences regarding whom victims of different types of bullying turn to for help: victims of verbal bullying (name-calling) report telling least, followed by indirect bullying victims (exclusion, having rumours spread about them), with victims of direct bullying (violence, property damage/theft) telling most (Elsea, 2001). 
Finally, Talamelli et al. (submitted) validated the efficacy of asking for help, reporting that students bullied over a 2 year period were significantly less likely to have used social support over that time than students beginning the same period as victims but ending it having resolved the situation. However, research to date has neglected to examine pupils' own views regarding how effective telling is at either stopping bullying or for helping them to cope with the emotions aroused. It is important these issues are adressed as the help pupils receive may focus on one of these two areas more comprehensively than the other, a finding that could help teachers, parents and peer-counsellors to develop more effective social support provision. Furthermore, Pearlin and Schooler (1978) have noted that how effective any coping strategy is cannot be judged solely on the ground of whether or not it removes a problem from one's life. Rather, they should be judged according to how well they prevent problems resulting in emotional stress.

Thus, we can begin to paint a picture of who seeks help for bullying problems: younger students more than older, girls more than boys, victims of direct bullying more than victims of indirect or verbal bullying. However, an understanding of why students ask for help is as important as knowing who asks for help since clarification of the motivation behind victims' requests for help will allow teachers/ parents/ peer-supporters to better understand what is being asked of them, and hence to provide a more appropriate and effective service.

In order to understand why children and adolescents do or do not tell anyone about their experience of victimisation and bullying it may be useful to frame telling as a coping 
behaviour. Coping has been defined as "the way people manage life conditions that are stressful" (Lazarus, 1999: 102) and can involve strategies which are Problem-Focused (directed toward managing or altering the problem causing distress) and EmotionFocused (directed at regulating the emotional response). For children or adolescents who are being bullied, an example of Problem-Focused coping might be telling a teacher in order to prevent the bullying recurring. An Emotion-Focused strategy might be playing a game so as to avoid thinking about the problem.

Process theories of coping (e.g. Lazarus, 1999) emphasise the role that one's perceptions of any given situation play in determining coping behaviour. Such perceptions, known as appraisals, include degree of perceived control over the stressor, threat (loss or harm which is anticipated), and challenge (where potential gains are emphasised) (Lazarus and Launier, 1978). These appraisals have been shown to be important determinants in coping strategy choice in a variety of different situations (e.g. Folkman, Lazarus, DunkelSchetter, DeLongis and Gruen, 1986; Ingledew, Hardy and Cooper, 1997; Kliewer, Fearnow and Walton, 1998).

In addition to appraisals, emotions also play a part in the coping process. In Lazarus' (1999) theoretical model, appraisals influence coping strategies, which in turn influence one's emotional reaction to events. However, Folkman and Moskowitz (2000) have noted that whether coping is viewed as determining emotion or vice versa depends upon whether our aim is to reduce psychological distress (where the focus would be on coping predicting emotion) or to predict who engages in particular behaviours (where the focus 
would be on emotions predicting coping). In the present research, the aim is to understand why children and adolescents tell someone when they are victimised; hence emotion is used here to predict use of a coping strategy (i.e. telling). Additionally, the order in which these processes occur is to some degree determined by practical factors and when considering victims of bullying asking for help, such behaviour would logically follow the experience of emotions within the bullying episode.

Process coping theories can, to some extent, help when formulating predictions regarding why victimised pupils ask for help. For example, the more controllable a pupil appraises peer-aggression to be the less they would be expected to tell someone since they perceive the situation as one which they can deal with themselves (see Folkman, Lazarus, DunkelSchetter, DeLongis and Gruen, 1986, for supporting evidence in adults). Similarly, the more negative emotion pupils report experiencing the more they might be expected to seek out help in order to deal with those emotions. However, different stressful situations are likely to present with specific patterns of relationships between appraisals, emotions and coping strategies since the demands and pressures of each will be unique. As a consequence, how these relationships are evidenced among the victims of peer aggression and bullying is a matter for empirical exploration.

Little research has examined either appraisal processes or emotions in the victims of school bullying. Hunter and Boyle (2002) examined the control appraisals that nine to 11 year old pupils held regarding bullying and report that frequently bullied girls have lower perceptions of control than infrequently bullied girls, a pattern which is absent in boys. 
Also, girls feel less in control of bullying than boys. In addition, pupils' perceptions of control are greatest when bullying first starts, but are reduced by its persistence. Using a retrospective methodology, Hunter, Mora-Merchan and Ortega (2000) found that Undergraduates reported that their perception of control was higher in Primary school than in Secondary school.

In a sample of nine to 14 year old students, Hunter \& Boyle (in press) found that the use of social support (measured using a coping survey, the Ways of Coping Checklist) was influenced by challenge appraisals. Specifically, pupils who were unsure of whether bullying was likely to have positive outcomes used more social support than pupils who felt bullying definitely would, or definitely would not, have positive outcomes. Additionally, challenge and control appraisals were both associated with wishful thinking coping and challenge appraisal was related to problem focused coping, indicating that appraisals do appear to be meaningfully related to pupils' choice of coping strategy.

The only article pertaining to emotional reactions of victims known to the authors is by Borg (1998), who examined the emotional reactions of nine to 14 year old victims after they had been bullied. He found that $38 \%$ felt vengeful (boys significantly more than girls; Secondary school pupils more than Primary), 37\% felt angry (Secondary more than Primary), $37 \%$ felt sorry for themselves (girls significantly more than boys; Secondary more than Primary), 25\% were indifferent, and 24\% felt helpless (Primary more than Secondary). 
In summary, researchers have identified several variables, such as gender and type of victimisation, which appear to influence whether or not students will ask for help when bullied. Telling seems to be an effective way of helping to stop bullying, but pupils own views regarding the effectiveness of telling have been neglected. Additionally, appraisal variables highlighted by coping theory, such as control, threat, and challenge seem to influence the type of coping strategies that victims of bullying use to deal with their predicament. Finally, the emotions experienced by victims of bullying have been examined, but these have not been placed within a coping framework.

\section{Aims}

1. To examine the effects that background variables (gender, school-stage), victimisation variables (duration, frequency), appraisal processes (threat, challenge, control) and negative emotions (e.g. anger, fear, guilt) have upon support seeking by child and adolescent victims of peer-aggression and bullying.

2. To examine the effectiveness of social support.

\section{Methodology}

\section{Participants}

Participants were 830 pupils (49\% male and 51\% female) aged between 9 and 14 years old attending mainstream schools in both North Lanarkshire and Aberdeenshire, Scotland. Primary School pupils were drawn from Primary Six classes in ten Primary Schools. Secondary Two and Three classes were drawn from five Secondary Schools. 
Two of the ten Primary Schools were denominational, while all other schools were nondenominational. Table 2 shows the breakdown of participants by school stage and gender.

\section{Table 2 about here}

\section{Materials}

A self-report questionnaire was developed based on a literature review. The questionnaire was designed to collect general victimisation information (prevalence, location, frequency, duration, etc.) as well as information specifically relating to appraisal, experienced emotion, coping, and bullying (i.e. bullying other students) and consisted of 66 items in total. Those reporting both victimisation and bullying completed all 66 items; those who were not victimised and did not bully others completed 54 items; those who were victimised and did not bully others completed 62 items; and those who were not victimised and did bully others completed 58 items.

The questionnaire began by presenting a list of ways in which children can be bullied, and the pupils were instructed: "Below is a list of ways that people can be nasty or unpleasant to other people. Has anyone been nasty to you, in any of these ways, in the past two weeks? If they have, tick that box and say how upset you were when it happened." Pupils indicated how upset they were when experiencing aggression using a 4-point Likert-type scale ( 1 = "not upset", $4=$ "very upset"). The list of aggressive behaviours was based on previous research (Hunter and Boyle, in press; McLean, 1994; Smith and Sharp, 1994) and included "Someone called you names", "You were 
threatened by someone", "Your belongings were stolen/damaged", "You were left out of games or groups", "You were hit or kicked", "Nasty stories were spread about you", "You were forced to do something you did not want to do" and "Other (please give example)". Following this list of behaviours, pupils were asked about how often they had experienced such behaviours ("Less than once a week", "About once a week", "Several times as week", "Every day", "Several times every day"). The duration was assessed by asking how long ago the aggression started ("This week", "A few weeks ago", "More than a month ago", "More than 6 months ago").

\section{Table 3 about here}

These questions were used to categorise children as non-victims, victims of peeraggression, and victims of bullying (see Table 3 for details). Following the most widely accepted definition of bullying (Whitney and Smith, 1993) children were categorised as victims of bullying if they experienced aggression which was likely to have been repeated in nature; as victims of peer-aggression if they had experienced aggression which was likely to have been non-recurring; and as non-victims if they reported experiencing no aggression over the past two weeks.

To measure threat and challenge appraisals pupils were asked "When other people are nasty to you, what do you think might happen?". This was followed by four statements relating to challenge appraisals ("You will learn to deal with bullying", "You will learn to be nice to others", "You will be a stronger, more confident, person", "The bully will be 
punished") and four relating to threat appraisals ("Your friends won't like you anymore", "You will be hurt physically (beaten up)", "You will feel bad about yourself", "More and more people will be nasty to you"). Each of the statements were rated on a 1 to 4 scale where 1 represented "Not likely" and 4 represented "Very likely". These measures were designed for this study, and all appraisal items were based on responses given by children in previous research (Hunter and Boyle, in press). The two measures displayed moderate reliability (challenge appraisals, Cronbach's alpha $=.56$; threat appraisals, Cronbach's alpha $=.63)$.

To measure students' control appraisals they were asked "How easy is it for you to stop other people being nasty to you?" and responses were again measured on a 1 to 4 scale, where 1 represented "Very difficult" and 4 represented "Very easy". Previous research using single-item measures of control, also with Likert-style response formats, have shown these to be effective measures of perceived control in both child/adolescent (Causey and Dubow, 1992; Kliewer et al., 1998) and adult (Chang, 1998; Pape and Arias, 1995) populations.

Details of how victims coped with bullying were measured using a checklist developed for the current study. The checklist of behaviours was based on coping responses which had been validated in previous research (Hunter et al., 2000; McLean, 1994; Miller, Verhoek-Miller, Ceminsky and Nugent, 2000; Sharp, 1995; Wilton, Craig and Pepler, 2000). The 'seeking social support' item required pupils to indicate how frequently they had told someone about what had been happening to them ("Never", "Once or twice", 
"Most of the time", or "Every time") and they were asked to say who they actually told, with three possibilities: friend, family, and/or teacher (pupils could indicate more than one). Other items on the checklist included "threatened to tell someone", "stood up to them, told them to stop", "tricked the bully", "tried to make friends with them", "wished you could change something", "hit them", "threatened to hit them", "stayed away from places they might be", "ignored them so they would stop", "kept your feelings to yourself", "made new friends", "did something to take your mind off the bullying", "cried", "told them how you felt", and "skipped school".

Effectiveness of telling was assessed by two items presented after the coping items. First, pupils were asked "Put a line under the ONE thing which was best for helping you to feel better (if nothing helped, then don't underline anything)" to examine how effective the strategy was for dealing with emotions aroused due to the aggression. Second, pupils were asked "Put an $X$ beside the ONE thing which was best at stopping people being nasty to you (if nothing helped, then don't put an X beside anything)" to examine how effective the strategy was for stopping the aggression. These measures had not been used previously, but were designed to reflect the two main aims of coping strategy use, namely, emotion regulation and problem solving (Lazarus, 1999).

To measure the emotions experienced by pupils when others were being aggressive toward them, nine emotion items were included. Pupils were asked "How did you feel WHEN THEY WERE BEING NASTY?" (emphasis in original) and were asked to rate the extent to which they experienced nine different emotions (anger, worry, fear, shame, 
sadness, jealousy, guilt, disappointment, and disgust) on a four-point scale ("Not at all", "A little", "Quite", "Very"). Each was based on the negative emotions outlined by Lazarus (1999), and the scale was piloted on a separate sample to check wording and understanding $(\mathrm{n}=236$, age range $8-14$ years $)$. The scale had satisfactory reliability $($ Cronbach's alpha $=.75)$.

The questionnaire also included a number of questions which were part of a broader research project (Hunter, 2003), but which are not relevant to the current study.

\section{Procedure}

The questionnaires were administered to whole classes by the first author in all but one Primary and two Secondary schools who preferred to administer the questionnaires themselves. As the questionnaires were NOT anonymous, all participants were reassured about confidentiality, and informed that the only information which would be relayed to their schools would be the names of pupils who reported experiencing bullying, in order that the school could offer them assistance (although there were concerns that this might have biased responses toward a reluctance to report victimisation, the prevalence rates reported were generally in-line with, and certainly no lower than, previous UK studies, e.g. Boulton and Underwood, 1992; Whitney and Smith, 1993). Following this, the whole questionnaire was read out item by item to the Primary school children, whereas Secondary school children were asked to complete the questionnaire with the researcher in the room to answer any questions. Instructions were given to those schools carrying out the questionnaire themselves to ensure procedural similarity. 


\section{Results}

\section{Prevalence}

Pupils were categorised into three groups: non-victims (those experiencing none of the forms of aggression listed), victims of peer aggression (those experiencing non-recurring aggression from their peers), and victims of bullying (those experiencing repeated aggression from their peers). This allowed 651 of the 830 pupils to be categorised (78\%), with the remaining pupils omitted due to incomplete data. Overall, $47 \%$ of the pupils were non-victims, $32 \%$ reported being victims of peer-aggression, and $21 \%$ reported being bullied.

To examine possible gender and school-stage effects in rates of victimisation, these 651 pupils were entered into a hierarchical log-linear analysis with gender, school-stage (P6, S2, S3) and victimisation category (non-victims, peer-aggression victims, bullying victims) as independent variables (see Table 4 for contingency table). All of the two-way contingency tables provided expected frequencies in excess of five, and after the model was selected none of the eight cells was an outlier. Stepwise selection by backward elimination of effects using SPSS produced a model with the following significant associations: school-stage $\mathrm{x}$ victimisation category and gender $\mathrm{x}$ victimisation category. This final model yielded a likelihood ratio $\chi^{2}(6)=4.31$, n.s., indicating a good fit between observed and expected frequencies (see Table 5). 
The gender $\mathrm{x}$ victimisation category association indicated that girls were more likely to be non-victims than would be expected by chance, while boys were more likely to be victims of peer-aggression and bullying than would be expected by chance. The schoolstage $\mathrm{x}$ victimisation category association appeared to indicate that there was a trend toward decreasing experience of aggression across all three school-stages, and this possibility was checked by carrying out two follow-up Chi Squares: the first examined P6 and S2 pupils on victimisation category, and this indicated a significant difference $\left(\chi^{2}(2)\right.$ $=11.72, \mathrm{p}<0.01)$. The second Chi Square examined S2 and S3 pupils on victimisation category, and this was again significant $\left(\chi^{2}(2)=9.75, \mathrm{p}<0.01\right)$. Hence, P6 pupils are more likely to experience aggression than S2 pupils, who are in turn more likely to experience aggression than $\mathrm{S} 3$ pupils.

\section{Table 4 about here}

Table 5 about here

\section{Telling}

Looking at the victims of both peer-aggression and bullying, a total of $78 \%$ reported telling someone about the problem. Eighty-six percent of victimised girls said they had told someone, compared to $64 \%$ of male victims. This represented $80 \%$ of victimised P6 pupils, $72 \%$ of victimised S2 pupils and $66 \%$ of victimised S3 pupils. Of these pupils, $52 \%$ told "Once or Twice", $28 \%$ told "Most of the Time" and 20\% told "Everytime" they had experienced aggression. 
Most pupils told either a friend (27\%) or a family member (28\%), followed by telling a friend and a family member (19\%) or a friend, a family member and a teacher (12\%). Pupils were relatively unlikely to tell a family member and a teacher (6\%), a friend and a teacher $(5 \%)$ or just a teacher $(4 \%)$. This data is broken down by school-stage and gender in Table 6

\section{Table 6 about here}

The influence of gender on who pupils would turn to for help was investigated using a gender $\mathrm{x}$ target (friend/ teacher/ family member/ friend and family member/ teacher and family member/ friend and teacher/ friend and teacher and family member) Chi-Square. This was non-significant, $\chi^{2}(6)=8.36$, n.s.

A second Chi-Square was calculated to examine whether school-stage influenced whom pupils turned to for help. Due to low expected frequencies when P6, S2 and S3 were all considered, the S2 and S3 data were collapsed into a single Secondary school category. This Chi-Square was non-significant, $\chi^{2}(6)=11.56$, n.s.

\section{Predicting Telling}

To examine how much influence gender, school-stage, victimisation, appraisal, and the degree of negative emotions pupils experienced while being bullied had upon the likelihood of their telling someone, the following variables were entered into a 
hierarchical stepwise multiple regression, with frequency of seeking support as the dependent variable:

- Block 1: gender (male, female); school-stage (P6, S2, S3); frequency of victimisation ("Less than once a week", "About once a week", "Several times as week", "Every day", "Several times every day"); duration of victimisation ("This week", "A few weeks ago", "More than a month ago", "More than 6 months ago")

- Block 2: average challenge appraisal; average threat appraisal; control appraisal

- Block 3: average negative emotion rating.

Tabachnick and Fidell (1996) recommend a cases-to-Predictor Variables ratio of 40-1 when using stepwise multiple regression. Since victims of peer-aggression and victims of bullying had a combined $\mathrm{n}$ of 305 (slightly below Tabachnick and Fidell's recommended 320 for eight Predictor Variables) these were not analysed separately.

A three variable regression model accounted for $15.8 \%$ of the support seeking variance $\left(\mathrm{R}^{2}=.158\right)$. Gender, itself, accounted for $8.7 \%$ of the variance $\left(\Delta \mathrm{R}^{2}\right.$ change $\left.=0.087\right)$, the average of the challenge items added $3.3 \%\left(\Delta \mathrm{R}^{2}\right.$ change $\left.=0.033\right)$ and the average of the emotion items added $3.8 \%\left(\Delta \mathrm{R}^{2}\right.$ change $\left.=0.038\right)$. School-stage, duration of victimisation, frequency of victimisation, threat appraisals and control appraisals were excluded from the model and did not account for any additional variance.

The average of the challenge items was not significantly correlated with the average of the emotion items $(r=0.088$, n.s. $)$ nor with gender $(r=0.081$, n.s. $)$. The average of the emotion items was correlated with gender $(r=0.161, \mathrm{p}<0.01)$, but still added 
independently to the amount of social support sought. The model is represented in Table 7.

\section{Table 7 about here}

\section{Best strategy}

Among both bullying victims and peer-aggression victims who reported that they had told someone about their experience of aggression, $24 \%$ felt it was the best strategy they had used for "stopping people being nasty to them". Of these $(\mathrm{n}=61), 18 \%$ had told a friend, $23 \%$ a family member, $26 \%$ a friend and a family member, and $20 \%$ had told a friend, family member and teacher. Only $3 \%$ had told a teacher and no one else, $3 \%$ a family member and a teacher, and $7 \%$ a friend and a teacher.

Twelve percent of all victims felt that telling was best strategy for "helping them to feel better". Who these students $(\mathrm{n}=27)$ had actually sought help from followed a similar pattern to above, with $19 \%$ telling a friends, $26 \%$ a family member, and $33 \%$ a friend and a family member. Thus, $78 \%$ of children endorsing telling as the best strategy had told a friend or a family member. A further $11 \%$ told a family member and a teacher, and a separate $11 \%$ told a friend, family member and a teacher. No one who felt that telling was best for making them feel better had told only a teacher, or just a friend and a teacher.

Due to problems with small expected frequencies in Chi-Square, gender and school-stage influences on the efficacy of telling were calculated by comparing those students saying 
telling was best with those students choosing any other strategy. These analyses revealed that girls who had told someone were significantly more likely to choose telling someone as the best strategy for stopping bullying $\left(\chi^{2}(1)=9.96, p<0.01\right)$ and making them feel better $\left(\chi^{2}(1)=9.00, p<0.01\right)$ compared to boys who had told someone (see Table 8 for observed values). There were no such differences regarding school-stage $\left(\chi^{2}(1)=0.20\right.$, n.s. for stopping bullying; $\chi^{2}(1)=1.82$, n.s. for making them feel better).

\section{Table 8 about here}

\section{Discussion}

The first aim of the research was to examine the effects that background variables (gender, school-stage), victimisation variables (duration, frequency), appraisal processes (threat, challenge, control) and negative emotion had upon support seeking by child and adolescent victims of peer-aggression and bullying. Results indicated that the most important factor appears to be gender, with girls more willing to seek out social support than boys. However, as the experience of negative emotion (during the victimisation episode) increases, so too does the seeking of social support. Also, pupils with more challenge appraisals regarding the victimisation situation are more likely to seek help. School-stage, duration/frequency of victimisation, and both threat and control appraisals did not increase the likelihood of reported help seeking behaviour beyond that predicted by gender, negative emotion, and challenge appraisals. 
With regards to the second aim of the research, examining how effective pupils perceive telling to be, it was discovered that girls were more likely than boys to endorse social support as the "best" strategy for stopping bullying and for helping them to "feel better". There were no differences according to school-stage.

The finding that girls were more likely than boys to seek help reflected previous findings (Glover et al., 2000; Hunter and Boyle, in press; Sharp, 1995; Talamelli et al., submitted). This result may reflect the finding reported here that girls perceive telling to be a more effective strategy, both in terms of stopping bullying and helping them to deal with their emotions. Future research should examine whether teachers treat boys and girls differently when they ask for help dealing with aggression, as this may be one reason for their different evaluations of telling. For example, teachers may be more dismissive of boys' feelings than they are of girls'.

The unique contribution of challenge appraisals to seeking social support indicates that pupils who see the possibility of the situation resulting in positive outcomes (such as personal growth or simply the bullying stopping) are more likely to seek help than those who do not. This result contrasts with Hunter \& Boyle (in press) who found no difference between pupils who saw no possibility of a positive outcome in response to peer aggression and those who did see the possibility of a positive outcome (though pupils who were unsure used more social support than either of these groups). Different measurements were used in the present study and, although the results differ, this 
suggests that challenge appraisals are important perceptions to investigate when we are trying to understand pupils' motivations when asking for help.

The unique contribution of negative emotion in predicting social support seeking indicates that many pupils may seek help as much to deal with their own negative emotions as to deal with the problem at hand. As such, this emphasises how important it is for victimised pupils to be given help dealing with their emotions and feelings as well as being given practical advice regarding stopping bullying. The importance of this is further emphasised by the finding that $24 \%$ of victims felt that telling was the best strategy they had used for "stopping people being nasty to them" but only $12 \%$ felt it was the best strategy for "helping them to feel better". These results indicate that teachers, parents and pupils need to be made more aware that when victims of peer aggression and bullying ask for help their emotions and feelings need to be considered as well as the practical problems facing them. However, whether pupils simply need a "sympathetic ear" or require more organised and substantial help, such as formal counselling, is likely to depend upon the degree of distress experienced. This could be a valuable area for future research to address.

Equally interesting were the findings that control and threat appraisals did not add unique variance to the prediction of social support seeking, indicating that these appraisals are less important than challenge appraisals regarding this particular coping strategy. This reflects the finding of Hunter \& Boyle (in press) who also found that challenge was the only appraisal related to their social support scale. However, given that the current 
research used a scale developed from Hunter \& Boyle's (in press) data, it may be the case that different threat appraisals may be more specifically related to "telling". For example, Naylor and Cowie (1999) reported that one of the things that stops pupils asking for help was fear of the bully; another example might be shame associated with asking for help. Future research in this area may thus benefit from a more detailed examination of threat appraisals specifically relating to the use of social support.

Additionally, results indicated that school-stage, and the frequency and duration of victimisation did not account for any unique variance beyond that accounted for by gender, challenge appraisals and emotions. If teachers are to increase their focus on the emotions of victims of peer-aggression, this suggests that there is no reason to differentiate this focus according to how long/ frequently pupils experience aggression, or what school-stage the pupils are in. Additionally, this indicates that previous research reporting developmental differences in seeking support (Borg, 1998; Glover et al., 2000; Hunter and Boyle, in press; Sharp, 1995) may need to be re-evaluated since such differences may not be present when appraisal and emotion variables are also examined.

The second aspect of the research, examining how effective pupils perceive telling to be, revealed that girls were more likely than boys to choose telling as the best strategy for both making them feel better and for stopping the aggression recurring. No school-stage differences were present. Of particular interest here were the findings that students predominantly told either friends or family members about the problems they experienced: 78\% of those who endorsed telling as best at "making them feel better" told 
friends or family, as did $67 \%$ of those who endorsed telling as best at "stopping people being nasty to them". Hardly any pupils who had only told a teacher endorsed this as the best strategy ( $3 \%$ for "stopping people being nasty", none for "making them feel better"). These statistics highlight two important points: first, that teachers themselves may need to be taught skills which better equip them to deal with both the practical and emotional sides of victimisation. Training courses do not usually provide prospective teachers with any basic counselling skills, but these may represent a valuable addition to course content. Second, that friends and family members are valuable allies in the drive to eliminate peer-victimisation and bullying in schools, and they should be involved as fully as possible in tackling the problem. This may take the form of more peer support initiatives as well as emphasising to pupils and parents how important it is that they take victims' concerns seriously, however trivial they may appear.

In addition to the practical implications of this research, the research provides support for the applicability of process theories of coping to the problems of children and adolescents coping with peer-victimisation and bullying. The research has shown that different aspects of the model (i.e. person and appraisal variables, as well as emotions) are indeed relevant when developing a greater understanding of why pupils seek social support. As has been noted, a broader range of appraisals and appraisal items may further enhance our understanding in this area.

A limitation of the current research is the self-report nature of the data collected. Future research would benefit from cross-validation of those aspects of the project which are 
amenable to peer- or teacher-report. Most obviously, teacher-, parent- and peer-reports of whether victims had actually sought help would be helpful in establishing measurement reliability.

Another limitation of the current research was that the measures of appraisal were measures of current appraisal, that is, how the pupils felt at the time the survey was administered. Given that appraisals are thought to change following coping strategy use (the process of "reappraisal", Lazarus, 1999) these may not accurately reflect the appraisals of pupils before they sought help. To overcome this problem, future research could ask pupils to record their appraisals and coping actions on a daily basis in order to monitor causal patterns in appraisal and coping, as well as allowing the process of reappraisal to be monitored. This is related to the more general weakness of the research, namely, that the data is cross-sectional, hence all causal inferences drawn here are tentative.

In conclusion, by using process theories of coping to examine the use of social support by child and adolescent victims of peer-aggression, not only has the utility of such theories been validated, but important predictors of social support use have been identified. These predictors have allowed us to re-examine the ways in which support might be offered to victims, as well as how we might encourage certain groups to seek more help. 


\section{References}

Borg, M.G. (1998). The emotional reactions of school bullies and their victims. Educational Psychology, 18 (4) 433-444.

Boulton, M.J. and Underwood, K. (1992). Bully/victim problems among middle school children. British Journal of Educational Psychology, 62 73-87.

Causey. D.L. and Dubow, E.F. (1992). Development of a self-report coping measure for elementary school children. Journal of Clinical Child Psychology, 21 (1), 47-59.

Chang, E.C. (1998). Dispositional optimism and primary and secondary appraisal of a stressor: Controlling for confounding influences and relations to coping and psychological and physical adjustment. Journal of Personality and Social Psychology, 74 (4) $1109-1120$.

Eslea, M. (2001). School bullying: Severity, distress and coping. British Psychological Society Centenary Annual Conference, SECC, Glasgow, 28 - 31 March.

Folkman, S., Lazarus, R.S., Dunkel-Schetter, C., DeLongis, A. and Gruen, R.J. (1986). Dynamics of a stressful encounter: Cognitive appraisal, coping, and encounter outcomes. Journal of Personality and Social Psychology, 50 (5) 992-1003. 
Folkman, S. and Moskowitz, J.T. (2000). Positive affect and the other side of coping. American Psychologist, 55 (6) 647-654.

Glover, D., Gough, G., Johnson, M. and Cartwright, N. (2000). Bullying in 25 secondary schools: Incidence, impact and intervention. Educational Research, 42 (2) 141-156.

Hunter, S.C. (2003). Coping with peer aggression and bullying: Antecedents, processes and outcomes. University of Strathclyde, Unpublished Ph.D. thesis.

Hunter, S.C. and Boyle, J.M.E. (2002). Perceptions of control in the victims of school bullying: The importance of early intervention. Educational Research, 44 (4) 323-336.

Hunter, S.C. and Boyle, J.M.E. (in press). Appraisal and coping strategy use in victims of school bullying. British Journal of Educational Psychology.

Hunter, S.C., Mora-Merchan, J.A. and Ortega, R. (2000). The long-term effects of coping strategy use in the victims of bullying: A cross-cultural study. XV CICA World Conference, Madrid, 9-11 July.

Ingledew, D.K., Hardy, L. and Cooper, C.L. (1997). Do resources bolster coping and does coping buffer stress? An organisational study with longitudinal aspect and control for negative affectivity. Journal of Occupational Health Psychology, 2 (2) 118-133. 
Kliewer, W., Fearnow, M.D. and Walton, M.N. (1998). Dispositional, environmental, and context-specific predictions of children's threat perceptions in everyday stressful situations. Journal of Youth and Adolescence, 27 (1) 83-100.

Lazarus, R.S. (1999). Stress and emotion: A new synthesis. London: Springer Publishing Company.

Lazarus, R.S. and Launier, R. (1978). Stress-related transactions between person and environment. In L.A. Pervin and M. Lewis (Eds) Perspectives in interactional psychology (pp287-327). London: Plenum Press.

McLean, A.V. (1994). Bullying survey in Strathclyde Region. Glasgow North East Psychological Service. Strathclyde Regional Council.

Miller, D.I., Verhoek-Miller, N., Ceminsky, J. and Nugent, C. (2000). Bullying in a school environment and its relationship with student satisfaction, performance, and coping reactions. Psychology: A Journal of Human Behavior, 37 (1) 15-19.

Naylor, P. and Cowie, H. (1999). The effectiveness of peer support systems in challenging school bullying: The perspectives and experiences of teachers and pupils. Journal of Adolescence, 22 467-479. 
Nicolaides, S., Toda, Y. and Smith, P.K. (2002). Knowledge and attitudes about school bullying in trainee teachers. British Journal of Educational Psychology, 72 (1) 105-118.

Pape, K.T. and Arias, I. (1995). Control, coping, and victimisation in dating relationships. Violence and Victims, 10 (1) 43-54.

Pateraki, L. and Houndoumadi, A. (2001). Bullying among primary school children in Athens, Greece. Educational Psychology, 21 (2) 169-177.

Pearlin, L.I. and Schooler, C. (1978). The structure of coping. Journal of Health and Social Behavior, 19 2-21.

Sharp, S. (1995). How much does bullying hurt? The effects of bullying on the personal wellbeing and educational progress of secondary aged students. Educational and Child Psychology, 12 (2) 81-88.

Smith, P.K. and Sharp, S. (1994). School bullying: Insights and perspectives. London: Routledge.

Tabachnick, B.G. and Fidell, L.S. (1996). Using multivariate statistics. USA: HarperCollins. 
Talamelli, L., Smith, P.K., Cowie, H., Naylor, P. and Chauhan, P. (Submitted). Profiles of non-victims, escaped victims, continuing victims, and new victims of school bullying. British Journal of Developmental Psychology.

Whitney, I. and Smith, P.K. (1993). A survey of the nature and extent of bullying in junior/ middle and secondary schools. Educational Research, 35 (1) 3-25.

Wilton, M.M.M., Craig, W.M. and Pepler, D.J. (2000). Emotional regulation and display in classroom victims of bullying: Characteristic expressions of affect, coping styles and relevant contextual factors. Social Development, 9 (2) 226-245. 
Table 1: Studies examining the use of social support among victims of school bullying.

\begin{tabular}{|l|l|l|l|}
\hline \multicolumn{1}{|c|}{ Study } & \multicolumn{1}{|c|}{ Sample } & Age Range & \multicolumn{1}{c|}{ Findings } \\
\hline $\begin{array}{l}\text { Borg (1998) } \\
\text { Self-report questionnaire }\end{array}$ & $\begin{array}{l}6,282 \\
\text { Maltese pupils }\end{array}$ & $9-14$ years & $\begin{array}{l}\text { Younger pupils more likely than older to seek help from friends, teachers, } \\
\text { and parents; girls more likely to seek help from best friend or parent; boys } \\
\text { more likely to seek help from a friend or teacher }\end{array}$ \\
\hline $\begin{array}{l}\text { Eslea (2001) } \\
\text { Self-report questionnaire }\end{array}$ & $\begin{array}{l}198 \\
\text { English pupils }\end{array}$ & $11-15$ years & $\begin{array}{l}16 \% \text { of pupils reported telling if called names, 22\% if rumours spread about } \\
\text { them, 25\% if physically hurt, and 49\% if belongings were stolen }\end{array}$ \\
\hline $\begin{array}{l}\text { Glover et al. (2000) } \\
\text { Self-report questionnaire }\end{array}$ & $\begin{array}{l}4,700 \\
\text { English pupils }\end{array}$ & $11-16$ years & $\begin{array}{l}\text { Younger pupils more likely than older to seek help; female pupils more likely } \\
\text { to seek help than male; telling a friend is most common, followed by mother, } \\
\text { and then form tutor }\end{array}$ \\
\hline $\begin{array}{l}\text { Hunter and Boyle (in press) } \\
\text { Self-report questionnaire }\end{array}$ & $\begin{array}{l}459 \\
\text { Scottish pupils }\end{array}$ & 9-14 years & $\begin{array}{l}\text { Younger pupils more likely than older to seek help; female pupils more likely } \\
\text { to seek help than male }\end{array}$ \\
\hline $\begin{array}{l}\text { Pateraki and Houndoumadi (2001) } \\
\text { Self-report questionnaire }\end{array}$ & $\begin{array}{l}1,312 \\
\text { Greek pupils }\end{array}$ & $7-11$ years & $\begin{array}{l}\text { Victims equally likely to ask adults and friends for help; bully-victims seem } \\
\text { less willing to seek help than victims }\end{array}$ \\
\hline $\begin{array}{l}\text { Sharp (1995) } \\
\text { Self-report questionnaire }\end{array}$ & $\begin{array}{l}703 \\
\text { English pupils }\end{array}$ & $\begin{array}{l}413 \\
\text { English pupils }\end{array}$ & $13-16$ years \\
\hline $\begin{array}{l}\text { Talamelli et al. (submitted) } \\
\text { Structured interviews }\end{array}$ & $\begin{array}{l}\text { Younger pupils more likely than older to seek help; female pupils more likely } \\
\text { to seek help than male }\end{array}$ \\
\hline & $\begin{array}{l}\text { Female pupils more likely to seek help than male; students most often spoke } \\
\text { to parents, followed by friends, teachers, then siblings; students reporting } \\
\text { being bullied over 2 year period less likely to have used social support than } \\
\text { pupils resolving bullying over the same period }\end{array}$ \\
\hline
\end{tabular}



Table 2: Participants. ${ }^{a}$

\begin{tabular}{|c|c|c|c|c|c|c|}
\hline \multirow{3}{*}{$\begin{array}{c}\text { School } \\
\text { Stage }\end{array}$} & \multicolumn{4}{|c|}{ Gender } & & \\
\hline & \multicolumn{2}{|c|}{ Male } & \multicolumn{2}{|c|}{ Female } & \multicolumn{2}{|c|}{ Total } \\
\hline & $N$ & $\%$ & $N$ & $\%$ & $N$ & $\%$ \\
\hline P6 & 154 & 49 & 163 & 51 & 317 & 38 \\
\hline$S 2$ & 151 & 49 & 155 & 51 & 306 & 37 \\
\hline$S 3$ & 98 & 48 & 107 & 52 & 205 & 25 \\
\hline Total & 403 & 49 & 425 & 51 & 828 & 100 \\
\hline
\end{tabular}

${ }^{\mathrm{a}}$ Two respondents did not indicate gender, and so are omitted from this table. 
Table 3:

Victim categorisation method: $B$ participants categorised as bullied;

$P A$ participants categorised as victims of peer-aggression.

\begin{tabular}{|r|c|c|c|c|c|}
\hline \multirow{2}{*}{ Start date } & \multicolumn{5}{|c|}{ Frequency of aggressive behaviours } \\
\cline { 2 - 6 } & $\begin{array}{c}\text { Less than } \\
\text { once a week }\end{array}$ & $\begin{array}{c}\text { About once } \\
\text { a week }\end{array}$ & $\begin{array}{c}\text { Several times } \\
\text { a week }\end{array}$ & $\begin{array}{c}\text { Every } \\
\text { day }\end{array}$ & $\begin{array}{c}\text { Several times } \\
\text { every day }\end{array}$ \\
\hline This week & PA & PA & B & B & $\mathrm{B}$ \\
\hline Few weeks ago & PA & PA & B & B & $\mathrm{B}$ \\
\hline Over a month & PA & B & B & B & B \\
\hline Over 6 months & PA & B & B & B & B \\
\hline
\end{tabular}


Table 4: Contingency table for gender, school-stage, and victimisation-category.

\begin{tabular}{|c|c|c|c|c|c|c|c|}
\hline \multirow[t]{2}{*}{ Gender } & \multirow[t]{2}{*}{$\begin{array}{c}\text { School- } \\
\text { stage }\end{array}$} & \multicolumn{2}{|c|}{ Non-victims } & \multicolumn{2}{|c|}{$\begin{array}{c}\text { Peer-Aggression } \\
\text { Victims }\end{array}$} & \multicolumn{2}{|c|}{ Bullying Victims } \\
\hline & & $\mathbf{n}$ & Row \% & $\mathrm{n}$ & Row \% & $\mathrm{n}$ & Row \% \\
\hline \multirow{3}{*}{ Male } & $P 6$ & 43 & 33 & 51 & 39 & 37 & 28 \\
\hline & $S 2$ & 54 & 47 & 36 & 31 & 25 & 22 \\
\hline & S3 & 29 & 54 & 14 & 27 & 9 & 17 \\
\hline \multirow{3}{*}{ Female } & $P 6$ & 57 & 39 & 52 & 36 & 37 & 25 \\
\hline & $S 2$ & 68 & 52 & 45 & 35 & 17 & 13 \\
\hline & S3 & 56 & 73 & 12 & 16 & 9 & 12 \\
\hline
\end{tabular}


Table 5: Results of hierarchical log-linear analysis of the effects of gender, schoolstage and victimisation category: Tests of partial association.

\begin{tabular}{|l|c|c|c|c|}
\hline \multicolumn{1}{|c|}{ Effect } & df & $\mathbf{G}^{\mathbf{2}}$ & $\mathbf{p}$ & Iteration \\
\hline $\begin{array}{l}\text { GENDER*SCHOOL- } \\
\text { STAGE*CATEGORY }\end{array}$ & 4 & 3.26 & 0.515 & 2 \\
\hline GENDER*SCHOOL-STAGE & 2 & 1.05 & 0.592 & 2 \\
\hline GENDER*CATEGORY & 2 & 6.04 & 0.049 & 2 \\
\hline SCHOOL-STAGE*CATEGORY & 4 & 34.74 & 0.0001 & 2 \\
\hline GENDER & 1 & 4.65 & 0.031 & 2 \\
\hline SCHOOL-STAGE & 2 & 60.53 & 0.0001 & 2 \\
\hline CATEGORY & 2 & 70.06 & 0.0001 & 2 \\
\hline
\end{tabular}

${ }^{\mathrm{a}} \mathrm{G}^{2}$ indicates the likelihood ratio, a measure of goodness of fit 
Table 6: Identity of person(s) whose help was sought.

\begin{tabular}{|r|c|c|c|c|c|}
\hline Identity & $\begin{array}{c}\text { Boys } \\
(\mathbf{N = 8 8})\end{array}$ & $\begin{array}{c}\text { Girls } \\
(\mathbf{N = 1 3 3})\end{array}$ & $\begin{array}{c}\text { P6 } \\
(\mathbf{N = 1 2 8})\end{array}$ & $\begin{array}{c}\text { S2 } \\
(\mathbf{N}=\mathbf{7 5})\end{array}$ & $\begin{array}{c}\text { S3 } \\
(\mathbf{N = 1 8})\end{array}$ \\
\hline Friend & $32 \%$ & $23 \%$ & $21 \%$ & $33 \%$ & $39 \%$ \\
\hline Family & 34 & 24 & 26 & 31 & 33 \\
\hline $\begin{array}{r}\text { Teacher } \\
\text { Friend and } \\
\text { Family }\end{array}$ & 5 & 4 & 4 & 4 & 6 \\
\hline $\begin{array}{r}\text { Friend and } \\
\text { Teacher }\end{array}$ & 3 & 23 & 20 & 20 & 6 \\
\hline $\begin{array}{r}\text { Family and } \\
\text { Teacher }\end{array}$ & 5 & 6 & 6 & 3 & 6 \\
\hline $\begin{array}{r}\text { Friend, } \\
\text { Family, and } \\
\text { Teacher }\end{array}$ & 9 & 7 & 7 & 5 & 0 \\
\hline
\end{tabular}


Table 7: Results of stepwise multiple regression analysis predicting social support.

\begin{tabular}{|l|c|c|c|c|c|c|}
\hline \multicolumn{1}{|c|}{ Step/ Predictor } & $\boldsymbol{R}$ & $\Delta \boldsymbol{R}^{\mathbf{2}}$ & $\begin{array}{c}\text { Increment } \\
\text { to } \Delta \boldsymbol{R}^{2}\end{array}$ & $\begin{array}{c}\boldsymbol{F} \text { for } \\
\text { change }\end{array}$ & $\boldsymbol{p}$ & $\begin{array}{c}\text { Final } \\
\boldsymbol{\beta}\end{array}$ \\
\hline Gender & 0.301 & 0.087 & 0.087 & 30.08 & $\mathrm{p}<0.01$ & 0.254 \\
\hline Challenge Appraisals & 0.355 & 0.120 & 0.033 & 12.40 & $\mathrm{p}<0.01$ & 0.175 \\
\hline Negative Emotion & 0.407 & 0.158 & 0.038 & 14.37 & $\mathrm{p}<0.01$ & 0.203 \\
\hline
\end{tabular}


Table 8: Efficacy of telling compared to other strategies.

\begin{tabular}{|r|c|c|c|c|c|}
\hline & \multicolumn{2}{|c|}{$\begin{array}{c}\text { Best strategy for "stopping people } \\
\text { being nasty to you" }\end{array}$} & & \multicolumn{2}{|c|}{$\begin{array}{c}\text { Best strategy for "helping you } \\
\text { to feel better" }\end{array}$} \\
\cline { 2 - 3 } \cline { 5 - 5 } \cline { 5 - 5 } \cline { 5 - 5 } & Telling & Other & Telling & Other \\
\hline Boys & $17(23.0 \%)$ & $57(77.0 \%)$ & & $5(8.1 \%)$ & $57(91.9 \%)$ \\
\hline Girls & $45(46.4 \%)$ & $52(53.6 \%)$ & & $24(27.9 \%)$ & $62(72.1 \%)$ \\
\hline P6 & $41(36.3 \%)$ & $72(63.7 \%)$ & & $18(17.3 \%)$ & $86(82.7 \%)$ \\
\hline S2 & $16(34.8 \%)$ & $30(65.2 \%)$ & & $11(26.8 \%)$ & $30(73.2 \%)$ \\
\hline S3 & $5(41.7 \%)$ & $7(58.3 \%)$ & & $1(14.3 \%)$ & $6(85.7 \%)$ \\
\hline
\end{tabular}

